\title{
The Role of Isotonic and Hypertonic Solutions in the Resuscitation of Shocked Patients
}

\author{
Colonel P J N Howorth, \\ TD, MSc MD FRCPath L/RAMC(V) \\ 208 (Merseyside) General Hospital RAMC(V)
}

SUMMARY: The role of intravenous salt solutions in resuscitation is reviewed historically. A brief account of the patho $\stackrel{\Phi}{\varrho}$ physiology of shock is given. The particular use of hypertonic solutions in the resuscitation of severely shocked patient is reviewed and its mechanism of action discussed. It is considered that hypertonic solutions may find a role in any futuremajor military conflict. Two hypertonic solutions that are suggested for consideration in this context are $12 \%$ sodium chloride. $(2 \mathrm{mmol} / \mathrm{ml})$ and $8.4 \%$ sodium bicarbonate $(1 \mathrm{mmol} / \mathrm{ml})$.

\section{ISOTONIC SALT SOLUTIONS}

\section{Introduction}

The use of intravenous (IV) salt solutions to resuscitate patients was first carried out in a logical, competent manner during the 1831 cholera epidemic in the UK. In cholera massive amounts of alkaline fluid are lost in the watery stool, leading to depletion of the extracellular fluid and a profound metabolic acidosis. The biochemical changes in the blood were elegantly summarised by O'Shaughnessy. ${ }^{1}$ Latta and his colleagues at the Cholera Hospital, Leith, successfully resuscitated several patients using a hypotonic salt solution given intravenously. The composition of this fluid was approximately:
$\mathrm{NaCl}$
$60 \mathrm{mmol} / \mathrm{l}$
$\mathrm{NaHCO}_{3} \quad 10 \mathrm{mmol} / 1$

and 91 was infused over 12 -h in one patient. ${ }^{2}$ It was appreciated at the time that the solution needed to be warmed to body temperature prior to administration, and the importance of avoiding air embolism was also known. ${ }^{3}$ This fascinating early work is fully reproduced in photocopy form in Howorth. ${ }^{2}$

Unfortunately, when the cholera epidemic burnt itself out this knowledge and experience were completely forgotten, perhaps because in 1833 Latta died and O'Shaughnessy emigrated to India where he later became the first Director General of the Indian Telegraph Service. (His work in linking Calcutta by telegraph to Bombay and Madras proved to be of great value in suppressing the Indian Mutiny. ${ }^{4}$

The value of IV salt solutions was rediscovered some 50 to 60 years later by obstetricians who realised that women dying of acute haemorrhage in childbirth still had enough blood remaining within the cardiovascular system to sustain life if only the blood volume could be restored. The use of blood transfusion itself was known to be risky; at that time $\mathrm{ABO}$ blood groups had not been discovered and it was not known how to prevent blood from clotting in vitro.

Thus Coates ${ }^{5}$ described the resuscitation of a patient after a massive post-partum haemorrhage by the IV in- fusion of $22 \mathrm{oz}(660 \mathrm{ml})$ water warmed to $100^{\circ} \mathrm{F}$. This was no wild adventure since Coates had previously tried $\vec{\omega}$ a saline-alcohol infusion in another patient, and he ex- $\vec{T}$ plained that although in theory IV water might result in "the red globules to swell up and cause them to yield the्gro pigment" this did not occur as checked by microscops.의 Coates was later largely instrumental in forming the Volunteer Medical Staff Corps in Manchester which wassc taken over by the War Office in 1887 and is the direst? ancestor of the present-day 207 (Manchester) Generato Hospital RAMC (TA). Elder $^{6}$ has given a full account of Coates's remarkable career.

Later on the use of "normal saline" gradually becafo established in treating acute haemorrhage". In 1891 famous surgeon W Arbuthnot Lane concluded a pasers on this subject with the aphorism "No person should बite of haemorrhage",8. It took nearly fifty years for thiso precept to become normal medical practice.

\section{World War One}

In the handbook issued to RAMC medical officers in 1915 there is no mention of IV saline or of blood transfusion ${ }^{9}$. However by the end of the war it was accepted that IV saline was of value in treating shock ${ }^{10}$. Cannon also realised that shock is accompanied by metabolic acidosis (described as a low alkaline reserve) and recommended IV bicarbonate to correct this ${ }^{11}$. Unfortunately the importance of this observation was overlooked when blood transfusion became more frequently used to supplement IV saline therapy.

\section{World War Two}

In the Western Desert in 1941 it was understood thato shocked, dehydrated casualties needed resusciation with IV fluids before surgery could be safely undertaken. Witho the setting up of the new Army Blood Transfusion Ser-N vice (a brilliant achievement) the early use of IV saline was complemented by IV plasma and $\mathrm{ABO}$-compatible ${ }_{\sigma}$ whole blood. During the 1944 Normandy campaign each 
100 casualties received on average 63 pints of whole blood, 63 pints of plasma, and a larger volume of IV saline.

\section{Post-World War Two}

It was gradually learned from using IV salt solutions to treat burns shock that inadequate volumes of fluid had been given in the past, since only about $1 / 3$ of infused saline is retained in the circulation ${ }^{12,13}$.

More recently there has been a move away from infusing saline towards more "physiological" salt solutions such as compound Na lactate (Hartmann's solution). The $\mathrm{K}$ at $5.0 \mathrm{mmol} / \mathrm{l}$ is intended to correct any tendency towards hypokalaemia, although hyperkalaemia usually accompanies the metabolic acidosis of shock. The lactate is converted into bicarbonate $(27 \mathrm{mmol} / \mathrm{l})$ in the liver, unless hypoxia is present, so that conversion will be slow in shock until recovery begins.

Virgilio et al ${ }^{14}$ showed that the circulation could be satisfactorily maintained after heavy blood loss due to major surgery (aortic reconstruction) by packed red cells and simple balanced electrolyte solutions, since in this situation the patient is not allowed to develop shock.

\section{Operation Corporate}

A simple and straightforward policy was adopted for resuscitation of casualties during the Falklands Islands campaign of 1982. IV fluids were given by large bore cannula into the forearm vein. All patients who required circulatory resuscitation received 11 compound $\mathrm{Na}$ lactate, followed by $0.5 \mathrm{~L}$ polygeline (Haemaccel). If further fluid was required this sequence was repeated or $\mathrm{ABO}$-group compatible blood was given ${ }^{15}$.

\section{Conclusion}

We can summarise the above work by saying that resuscitation with isotonic electrolyte solutions is quite feasible provided that:

(1) there are sufficient red cells in the circulation to transport adequate amounts of oxygen to the tissues.

(2) the patient is not badly shocked, which depends not so much on the amount of fluid lost as on the time interval between trauma and resuscitation.

\section{Patho-physiology of shock}

Before discussing the role of hypertonic solutions in resuscitation, it would be helpful to outline the sequence of changes which may follow trauma and result in progressive cardiovascular collapse, or shock. Although shock can result from sepsis and cardiac causes, we are mainly concerned here with hypovolaemic shock due to trauma and haemorrhage. Shock is usually described in four stages:

\section{Stage 1: Vasoconstriction}

Trauma or haemorrhage result in the sudden secretion of catecholamines and other vasoactive substances which cause intense arteriolar vasoconstriction. However blood flow is maintained in vital organs, particularly the heart and brain. Sympathetic stimulation results in the wellknown features of early shock such as the pale, sweating skin and rapid thready pulse.

Stage 2: Expansion of the vascular space

The generalised vasoconstriction causes the cells to become hypoxic and a metabolic acidosis ensues. As a result of oxygen demand from the tissues all capillaries open up resulting in a slowing of capillary perfusion which further aggravates the acidosis. The blood becomes hypercoagulable, and the viscera (lungs, liver, kidneys) are congested.

Stage 3: Disseminated intravascular coagulation

In late shock capillaries become blocked by clots and the blood may then become incoagulable resulting in oozing of blood from wounds even if sutured. Cells formerly nourished from the blocked capillaries start to die. Shock at this stage is resistant to treatment but is still reversible.

Stage 4: Irreversible haemorrhageic shock

It is never clinically certain when tissue death and necrosis have reached the point of no return, since death of cells begins as a local event and becomes progressive. Given that attempts at resuscitation are made, the capillary circulation may be restored since clots will be lysed by endogenous fibrinolysin. Depending upon the extent of necrosis "multiple organ failure" may result in death ${ }^{16}$.

Shock affects the major organs in different ways:

\section{Heart}

Myocardial depression is the main feature and is thought to follow myocardial ischaemia or the release of myocardial depressant factor from hypoxic pancreatic acinar cells.

\section{Lungs}

Shock respiratory distress syndrome results from pulmonary oedema and alveolar collapse. Although in early shock there is often a low $\mathrm{PCO}_{2}$ and normal $\mathrm{PO}_{2}$ due to hyperventilation, in severe cases the $\mathrm{PO}_{2}$ may be low from the outset.

\section{Kidneys}

The kidney is very vulnerable to ischaemia since the renal blood flow is normally $25 \%$ of the cardiac output and during shock the renal blood flow and oxygen consumption fall markedly, particularly in the cortex. Urine output ceases when the arterial BP drops to $50 \mathrm{~mm} \mathrm{Hg}$. As renal perfusion falls so $\mathrm{Na}$ reabsorption is reduced in the tubules allowing $\mathrm{Na}$ loss into the urine. In severe shock acute renal failure may develop.

\section{Liver}

Liver damage is an early, common finding in shock and follows reduction in hepatic blood flow and oxygen consumption. Centrilobular necrosis is seen histologically. 
With adequate resuscitation recovery of liver function is usual and persistent jaundice is a bad prognostic $\operatorname{sign}^{17}$.

\section{Resuscitation using hypertonic solutions}

We have seen that significant advances in resuscitation techniques were made in both World Wars. It is easy to anticipate that in the event of a major conflict in the future there may be resupply problems with both colloids and whole blood. It is of interest therefore to review the small but valuable literature on the use of hypertonic solutions to resuscitate dogs and humans in severe shock (Stages 2-4). Three types of hypertonic solution have been used:

(1) neutral saline $(\mathrm{NaCl})$

(2) alkaline $(\mathrm{NaHCO})_{3}$

(3) non-electrolyte (glucose or mannitol).

Mixtures have also been used.

\section{(1) Brooks et al ${ }^{18}$}

Brooks et al ${ }^{18}$ experimented on 39 dogs bled to a mean arterial BP $40 \mathrm{~mm} \mathrm{Hg}$ giving acute haemorrhagic shock of 90 min duration. Dogs did not survive resuscitation with isotonic fluids, but survival was excellent after resuscitation with either $2.74 \% \mathrm{NaHCO}_{3}(325 \mathrm{mmol} / \mathrm{l})$ or $1.8 \% \mathrm{NaCl}(300 \mathrm{mmol} / \mathrm{l})$. There was a small suggestion that $\mathrm{NaCO}_{3}$ was better than $\mathrm{NaCl}$; it has the theoretical advantage of correcting the metabolic acidosis of shock. $10 \%$ glucose $(555 \mathrm{mmol} / \mathrm{l})$ was found to be ineffective in dogs.

Brooks also gave a case-report on the use of a hypertonic IV fluid on a 72-year-old man with acute renal failure.

The composition of the fluid was:

\begin{tabular}{lr}
$\mathrm{NaHCO}$ & \\
$\mathrm{NaCl}$ & $166 \mathrm{mmol} / \mathrm{l}$ \\
Glucose & $75 \mathrm{mmol} / \mathrm{l}$ \\
\hline Total & $119 \mathrm{mmol} / \mathrm{l}$ \\
\hline
\end{tabular}

\section{(2) McNamara et $a l^{19}$}

McNamara and his colleagues ${ }^{19}$ studied 31 Vietnam War combat casualties admitted to the US 24th Evacuation Hospital in hypovolaemic shock (arterial BP $<90 \mathrm{~mm}$ $\mathrm{Hg}$; pulse rate $>120 / \mathrm{min}$ ). Their patients had already received conventional resuscitation en route including IV electrolytes and blood transfusion. They reported that $50 \%$ glucose, $1 \mathrm{ml} / \mathrm{kg}$, injected IV over $45 \mathrm{sec}$ gave the best results, with significantly sustained elevation in BP and pulse pressure. Blood lactate fell but blood $\mathrm{pH}$ altered little. Saline given as $3 \% \mathrm{NaCl}(510 \mathrm{mmol} / \mathrm{l}), 2.7 \mathrm{ml} / \mathrm{kg}$, or mannitol, $25 \%$ solution, $2 \mathrm{ml} / \mathrm{kg}$, given as an equivalent osmotic load were both less effective than IV glucose; elevations in BP and pulse pressure occurred but were lower and of shorter duration.

\section{(3) Jelenko et $a t^{20}$}

Jelenko and colleagues ${ }^{20}$ resuscitated 12 civilian burns casualties using two hypertonic solutions:
(1) $\mathrm{NaCl}$
$120 \mathrm{mmol} / \mathrm{l}$
$\mathrm{Na}$ lactate
$120 \mathrm{mmol} / \mathrm{l}$
Total
$240 \mathrm{mmol} / \mathrm{l}$

(2) As above, plus added albumin, $12.5 \mathrm{~g} / 1$.

Resuscitation was found to be more rapid and requiredo lower volumes using solution (2), but the hypertonic elec- $\frac{\bar{s}}{\bar{\rho}}$ trolyte solution (1) was still superior to ordinary IV Ringer-lactate solution $(130 \mathrm{mmol} / \mathrm{l})$.

\section{(4) de Filippe et $a l^{21}$}

de Felippe and colleagues ${ }^{21}$ attempted to resuscitate $12 \overrightarrow{\vec{\omega}}$ patients admitted to their intensive care unit at Sao Paulog in refractory shock (Stage 3-4). Patients had been in shockल $5-22 \mathrm{~h}$, had arterial hypotension (BP $<70 \mathrm{~mm} \mathrm{Hg}$ ) and 3 had low or absent urine flow. Shock was reversed in $11 / 12$ ? patients by giving $7.5 \% \mathrm{NaCl}(1280 \mathrm{mmol} / \mathrm{l}), 100-400 \mathrm{ml}$ IV, although three patients subsequently died. The im-i mediate effects seen were a moderate rise in arterial B⿻ the resumption of urine flow, and recovery of coif -6 sciousness. These effects lasted for several hours.

\section{Discussion}

It has been standard medical practice for the last years to resuscitate shocked patients with IV isotonic eletrolyte and colloid solutions, adding packed red cells gro whole blood if the haematocrit falls to $30 \%$. Trends an. recent years have been to use compound $\mathrm{Na}$ lactate electrolyte and polygeline as colloid in place of simpte saline and Dextran. Polygeline is not mentioned in the 1981 Field Surgery Pocket Book ${ }^{22}$, although it was the colloid of first choice in the 1982 Falklands campaign ${ }^{15} \stackrel{\mathbb{D}}{\varrho}$

The wisdom of replacing IV saline $(150 \mathrm{mmol} / \mathrm{l})$ by $\overrightarrow{\vec{F}}$ compound $\mathrm{Na}$ lactate $(140 \mathrm{mmol} / \mathrm{l})$ can be questioned. 3 Although intended to correct the metabolic acidosis of shock it will be least effective in the worst injured pa-0 tients, since it requires an active liver to convert lactate to bicarbonate. It is now obsolete to give IV Na lactate in diabetic ketoacidosis; when correction of serious metabolic acidosis is necessary (arterial $\mathrm{H}^{+}$greater than $100 \mathrm{mmol} / \mathrm{l}: \mathrm{pH}$ less than 7.0) 50-100 mmol IV $\mathrm{NaHCO}_{3} \stackrel{\mathrm{N}}{=}$ are given, with measurement of arterial blood $\mathrm{pH}$ to monitor the procedure ${ }^{3}$.

This paper was written primarily to suggest the use of hypertonic solutions to resuscitate severely shocked pa-을 tients in any future major military conflict. There is insufficient evidence in the papers cited above to decide $\frac{}{5}$ which of the various solutions used is the best. Saline $?$ alone is simplest and cheapest, and meets military requirements about availability under arduous field con- No ditions, but the work of McNamara et al $^{19}$ using $50 \% 0^{\circ} \mathrm{N}$ glucose $(2.8 \mathrm{mmol} / \mathrm{ml})$ would merit investigation if the opportunity arose. Brooks ${ }^{23}$ commented that the strength of hypertonic solutions used by different workers? is arbitrary, but that since isotonic electrolytes will have alreadv heen infused it would he lnoisal to uce ctronner 
solutions such as $10 \%$ sodium chloride. The best clinical results in the work reviewed above were obtained by McNamara et $\mathrm{al}^{19}$ and de Felippe et $\mathrm{al}^{21}$ using $50 \%$ glucose $(2.8 \mathrm{mmol} / \mathrm{ml})$ and $7.5 \% \mathrm{NaCl}(1.3 \mathrm{mmol} / \mathrm{ml})$ respectively.

The mechanism whereby hypertonic solutions produce a dramatic response in shock is presumably that they correct the almost isotonic shift of sodium and water from the extra-cellular fluid into the cells which is known to occur in haemorrhagic shock ${ }^{24}$. Using ${ }^{131} \mathrm{I}$-albumin to measure plasma volume and ${ }^{35} \mathrm{~S}$-sulphate to measure extra-cellular fluid water Shires ${ }^{24}$ was able to demonstrate quite clearly that in haemorrhagic shock the loss of extra-cellular fluid volume was much greater than the actual blood volume lost from the circulation. By measuring resting transmembrane potential (P.D.) in skeletal muscle cells Carrico et $\mathrm{al}^{24}$ showed a fall in membrane P.D. accompanied by a fall in blood pressure and rise in extra-cellular fluid potassium concentration in haemorrhagic shock. The hypoxia of shock leads to impaired functioning of the $\mathrm{Na} / \mathrm{K}$-activated AT-Phase which controls $\mathrm{Na}$ transport; raising the plasma osmolality may help to correct the ionic shifts in "sick cells" and their surroundings.

It is likely that administration of hypertonic fluids will be most effective when first used and that repetition will bring a diminishing response. There is only a relatively small amount of water in the cells which can be "pulled out" over and above the entry in shock referred to above. In severe dehydration death occurs when about $12.5 \%$ body weight has been lost, equivalent to about 91 water or $1 / 5$ th total body water in a $70 \mathrm{~kg}$ adult, but in this situation water is usually lost over several days. In acute haemorrhage death usually occurs if more than 3-4 I blood is lost without fluid replacement.

Since under field conditions a simple IV resuscitation regime is required it is suggested the two hypertonic solutions might be used in severe (Stage 2-3) shock. As a simple saline solution $12 \% \mathrm{NaCl}$ containing $2.0 \mathrm{mmol} / \mathrm{ml}$ and given in $100 \mathrm{ml}$ quantities would make for simplicity in recording therapy. A second solution to be considered is $8.4 \% \mathrm{NaHCO}_{3}$ which is generally available and contains $1 \mathrm{mmol} / \mathrm{ml}$. Up to $50 \mathrm{ml}$ could be safely given in severe shock without measurement of blood gases, but if these measurements were available more could be given if required. de Felippe et $\mathrm{al}^{21}$ gave up to $500 \mathrm{mmol} \mathrm{NaCl}$ as a $7.5 \%$ solution; $200 \mathrm{ml} 12 \% \mathrm{NaCl}$ and $50 \mathrm{cl} 8.4 \% \mathrm{NaHCO}_{3}$ contain $450 \mathrm{mmol}$ and would therefore be comparable therapy with the added advantage of helping to correct the acidosis of shock which has been recognised as necessary for over 150 years ${ }^{1-3}$.

\section{REFERENCES}

1. O'Shaughnessy, W B. Experiments on the blood in cholera. Lancet 1831-2; 1: 490.

2. HowORTH, P J N. The physiological assessmentof acidbase balance. $B r J$ Dis Chest 1975; 69: 75-102.

3. LAtTA, T. Malignant cholera: Documents communicated by the Central Board of Health, London, relative to the treatment of cholera by the copious injection of aqueous and saline fluids into the veins. Lancet 1831-2; 2: 274-278.

4. Annotation: A medical Director-General of Indian telegraphs, $\mathrm{Br}$ med $J$ 1902; 1: 40.

5. COATES, W. Two cases of intravenous injection of fluids for severe haemorrhage. Lancet 1882; 2: 1110-1112.

6. Elder, W M. Sir William Coates in Some Manchester Doctors, eds Elwood W J and Tuxford A F. University Press: Manchester 1984, 113-115.

7. SPENCER H R. Intravenous injections of "normal" salt solutions for the grave haemorrhages of midwifery. Lancet 1892; 1: 1289-1291. 1357-1359.

8. LANE W A. A surgical tribute to the late Dr Wooldridge. Lancet 1891; 2: 626-627.

9. Mclaughlin, R. The Royal Army Medical Corps Cooper: London 1972, $a$ p. $45, b$ p. 87.

10. CANNON, W B. Some characteristics of shock induced by tissue injury. Med Res Coun Spec Rep 1919; Ser No 26:: 27-32.

11. Cannon, W B, Fraser, J and Cowell, E M. Preventiveo treatment of wound shock. J Amer Med Assoc 1918; 70: 618-621.

12. COLler, F A et al. Translocation of fluid produced by theo intravenous administration of isotonic salt solutions in mane postoperatively. Ann Surg 1945; 122: 663-677.

13. REYNOLDS, M. Cardiovascular effects of large volumes of isotonic saline infused intravenously into dogs following severe haemorrhage. Amer J Physiol 1949; 158: 418-428,

14. VIRGILIO, R W et al. Crystalloid vs colloid resuscitation: is one better?, a randomized clinical study. Surgery 1979; 85: $129-139$.

15. Williams, J G, Riley, T R D and MoOdy, R A. Resuscitation experience in the Falklands Islands campaign. $\mathrm{Br} \mathrm{Med}$ $J$ 1983; 286: 775-777

16. Ledingham, I McA, Cowan B N and Burns, H J G. Prognosis in severe shock. $\mathrm{Br} \mathrm{Med} J$ 1982; 284: 443-444.

17. LedinghaM, I McA and RouTH, G S. The pathophysiology of shock. Br J Hosp Med 1979; 22: 472-482.

18. Brooks, D K et al. Osmolar and electrolyte changes in haemorrhagic shock: hypertonic solutions in the prevention of tissue damage. Lancet 1963; 1: 521-527.

19. MCNamara, I J et al. Effect of hypertonic glucose in hypovolaemic shock in man. Ann Surg 1972; 176: 247-250.

20. JELENKO, C et al. Studies in shock, I: use of a hypertonic, albumin-containing, fluid demand regimen (HSLFD) in resuscitation. Critical Care Med 1979; 7: 157-167.

21. de FELIPPE, J et al. Treatment of refractory hypovolaemic shock by $7.5 \%$ sodium chloride infections. Lancet 1980 ; 2; 1002-1004.

22. Field Surgery Pocket Book, EDS Kirby $\mathbf{N}$ G and Blackburn G, 2nd edn. HMSO: London 1981; Ch 1981; Ch. 3: shock and resuscitation, pp.34-49.

23. BRooks, D. K. Treatment of refractory hypovolaemic shock. (Letter). Lancet 1980; 2: 1256.

24. Carrico, C J, Canizaro, P C and Shires, G T. Fluid resuscitation following injury: rationale for the use of balanced salt solutions. Crit Care Med 1976; 4: 46-54. 


\section{THE ROLE OF ISOTONIC AND HYPERTONIC SOLUTIONS IN THE RESUSCITATION OF SHOCKED PATIENTS}

\author{
From Col $R$ Scott, $L / R A M C$, Professor of Military \\ Surgery
}

The interesting paper by Colonel $\mathrm{P} J \mathrm{~N}$ Howorth brings to mind the discussions concerning the role of hypertonic solutions in the treatment of cholera victims.

This treatment was gradually given up in favour of isotonic saline and in a recent authoritative review Flear et al recommend isotonic rather than hypertonic solutions for the correction of salt depletion. ${ }^{2}$

Although the wounded soldier may be dehydrated, and in some areas may also be salt depleted, blood loss is the principal reason for the need to restore the circulatory volume. The biochemical changes following blood loss are so complex that it takes a chemical pathologist to understand them; nevertheless military surgeons have been impressed by the value of replacement of lost bloodes? by Ringer lactate solution, providing that it is not used in amounts in excess of 2 litres.

There may be logistic advantages in the stock-pile and use of hypertonic solutions and this is currently being in $-\frac{\bar{\sigma}}{\bar{\phi}}$ vestigated in the United States. We await the outcome of these investigations with interest but, in the meantime, $\varrho$ we do not think that there should be any change in thes resuscitation policy or in the holding policy for resuscita- $\overrightarrow{0}$ tion fluids.

\section{REFERENCES}

1. RoGers $L$ and MacKelvie, $M$. Note on the value of large quantities of hypertonic salt solutions in transfusion for cholera. Indian Medical Gazette 1908; XLIII: 165-167. $\vec{\omega}$

2. FleAR, C T G, GILL.. G V and BURN. J. Hyponatraemia: Mechanisms and Management. Lancet 1981; 11: 26-31. O

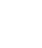

